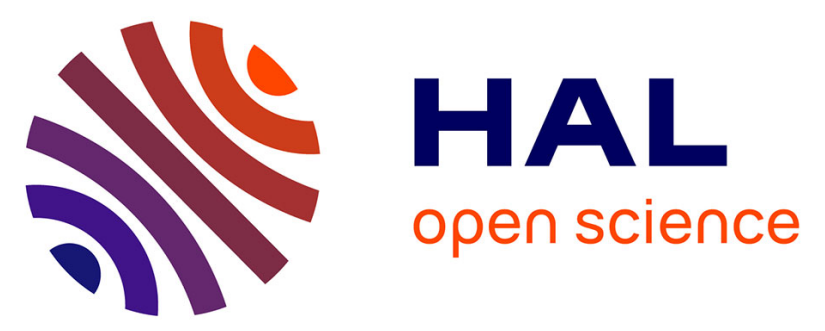

\title{
Effects of age and dietary fibre level on caecal microbial communities of conventional and specific pathogen-free rabbits
}

N. Bennegadi, Gérard Fonty, L. Millet, Thierry Gidenne, Dominique Licois

\section{- To cite this version:}

N. Bennegadi, Gérard Fonty, L. Millet, Thierry Gidenne, Dominique Licois. Effects of age and dietary fibre level on caecal microbial communities of conventional and specific pathogen-free rabbits. Microbial Ecology in Health and Disease, 2003, 5, pp.23-32. 10.1080/08910600310015574 . hal-02675212

\section{HAL Id: hal-02675212 \\ https://hal.inrae.fr/hal-02675212}

Submitted on 31 May 2020

HAL is a multi-disciplinary open access archive for the deposit and dissemination of scientific research documents, whether they are published or not. The documents may come from teaching and research institutions in France or abroad, or from public or private research centers.
L'archive ouverte pluridisciplinaire HAL, est destinée au dépôt et à la diffusion de documents scientifiques de niveau recherche, publiés ou non, émanant des établissements d'enseignement et de recherche français ou étrangers, des laboratoires publics ou privés. 


\section{Effects of Age and Dietary Fibre Level on Caecal Microbial Communities of Conventional and Specific Pathogen-Free Rabbits}

\section{Nadia Bennegadi, Gérard Fonty, Liliane Millet, Thierry Gidenne \& Dominique Licois}

To cite this article: Nadia Bennegadi, Gérard Fonty, Liliane Millet, Thierry Gidenne \& Dominique Licois (2003) Effects of Age and Dietary Fibre Level on Caecal Microbial Communities of Conventional and Specific Pathogen-Free Rabbits, Microbial Ecology in Health and Disease, 15:1, 23-32

To link to this article: http://dx.doi.org/10.1080/08910600310015574

$$
\begin{aligned}
& \text { (c) } 2003 \text { The Author(s). Published by Taylor \& } \\
& \text { Francis. }
\end{aligned}
$$

曲 Published online: 11 Jul 2009.

\section{Submit your article to this journal $\sqsubset$}

山 Article views: 29

View related articles $\sqsubset$ 


\title{
Effects of Age and Dietary Fibre Level on Caecal Microbial Communities of Conventional and Specific Pathogen-Free Rabbits
}

\author{
Nadia Bennegadi ${ }^{1}$, Gérard Fonty ${ }^{2}$, Liliane Millet $^{2}$, Thierry Gidenne ${ }^{1}$ and \\ Dominique Licois ${ }^{3}$
}

From the ${ }^{1}$ Station de Recherches Cunicoles, INRA, CR Toulouse, BP 27, 31326 Castanet-Tolosan, France, ${ }^{2}$ Laboratoire de Microbiologie, INRA, CR Clermont-Ferrand, Theix, 63122 Saint-Genès-Champanelle, France and ${ }^{3}$ Laboratoire de Pathologie du Lapin, Station de Pathologie Aviaire et de Parasitologie, INRA, CR Tours, 37380 Nouzilly, France

Correspondence to: Gérard Fonty, Laboratoire de Microbiologie, INRA, CR Clermont Ferrand, Theix, FR-63122 Saint-Genès-Champanelle, France. Tel.: + 33 (0)4 736242 45; Fax: + 33 (0)4 736245 81; E-mail: fonty@clermont.inra.fr

\begin{abstract}
Microbial Ecology in Health and Disease 2003; 5: 23-32
Caecal community structure in conventional and specific pathogen-free (SPF) rabbits was assessed by performing dot-blot hybridization with 16S rRNA targeted oligonucleotide probes. The variation of the caecal flora was analysed according to age (18-70 days old), nutritional status (acid detergent fibre $=19 \%$ in standard and $9 \%$ in fibre-deficient diet) and rabbit health (healthy vs diarrhoeic). Caecal flora was stabilized at around 25-28 days. Bacteria and archaea represented $73 \%$ and $22 \%$, respectively, of the total microbial communities at weaning (28 days). Cellulolytic bacteria (Ruminococcus albus, R. flavefaciens, Fibrobacter succinogenes and F. intestinalis) represented $<7 \%$ of total bacteria, with a predominance of $R$. flavefaciens and $R$. albus, respectively, for conventional and SPF rabbits. Bacterial and archaeal rRNAs were twofold higher in conventional than in SPF rabbits, fed standard diet $(p<0.001)$. In conventional rabbits, archaeal community was twofold higher with standard diet than with fibre-deficient diet. In both types of rabbits, quantities of Flexibacter-Cytophaga-Bacteroides rRNA were twofold higher with fibre-deficient diet than with standard diet. In diarrhoeic conventional rabbits, the proportion of eukaryal rRNA increased 4-fold, but proportions of bacterial and archaeal rRNA decreased by 1-, 2- and 6 -fold, respectively. The quantities of rRNA of $F$. succinogenes and $F$. intestinalis in conventional rabbits were, respectively 17 and 5 times higher in sick than in healthy animals, and decreased by 7 -fold for $R$. albus. This study shows some microbial interactions according to nutrition and health of the rabbit. Key words: rabbit, caecal flora, fibre deficiency, oligonucleotide probes, enteropathy, specific pathogen-free, microbial community balance.
\end{abstract}

\section{INTRODUCTION}

Rabbit production is currently affected by two predominant syndromes: digestive and respiratory pathologies. The intestinal pathology is mostly encountered in the growing rabbit after weaning (6-8 weeks of age), leading to high mortality and morbidity. The mortality rate after weaning reaches 14\% in France (1) but may frequently exceed 20\% in cases of specific pathologies such as Escherichia coli O103 and Clostridium spiroforme outbreaks. Loss of performance (low growth, low feed intake and poor feed conversion) due to a transient diarrhoea is also costly, but remains difficult to quantify. Diarrhoea is the main clinical symptom of enteropathy (2). However, the diagnosis is difficult because symptoms and lesions are generally similar, while digestive pathology can have two main origins: pathogenic agents (parasites, bacteria, viruses) or the environment including modifications of nutritional factors and breeding conditions (hygiene and stress) (3). Among the nutritional factors, the level of fibre in the diet is probably one of the most important. In rabbits, plant fibres are primarily digested in the caecum and the proximal colon (4), by the complex and very diverse microbial community inhabiting these two biotopes. Caecal fermentation is believed to have an important role in the nutrition and health of rabbits, particularly around the weaning period. The maturation of the caecal microbial ecosystem evolves according to the age of the rabbit (5) and time after weaning (6). Emaldi et al. (7) indicated that the main microbial activities in the caecum are, in decreasing order, ammonia use, ureolytic, proteolytic and cellulolytic activities. The predominant caecal and colonic bacterial species belong to the genus Bacteroides $\left(10^{9}-10^{10}\right.$ bacteria $\mathrm{g}^{-1}$ digestive content) $(5,8)$. The cellulolytic bacterial community appears around 2 weeks after birth (9). This community was found to be dominated by Eubacterium cellulosolvens and Bacteroides spp. (9). Some data indicate 
that the nature of the feed can greatly affect the composition of the caecal ecosystem $(6,9-11)$. To date, the effect of microbial status (conventional and SPF) on rabbit digestion and health has only been investigated by Licois and Coudert (12). These authors observed that the mortality and the morbidity rates of SPF rabbits experimentally infected to reproduce epizootic enterocolitic syndrome were low $(10-15 \%)$, whereas the mortality in conventional rabbits was higher than $60 \%$.

We have recently investigated the effect of dietary fibre level and of microbial status on the enteropathy of growing rabbits. The part of this work dealing with growth performance and observations of digestive disturbances (morbidity and mortality rate) has already been published (13). The present paper describes the microbiological aspects of this investigation. Our objectives were: 1) to investigate the evolution of some caecal microbial communities during the weaning period of growing rabbits fed a standard diet, 2) to study the impact of a fibre-deficient diet on the balance of these communities (particularly the fibrolytic population), 3) to determine the differences in microbial flora composition in conventional and SPF rabbits, 4) to compare, in conventional rabbits, the caecal microflora of sick animals with that of healthy animals. To achieve these goals, detection and quantification of microbial populations were assessed by dot-blot hybridization with phylogenetically $16 \mathrm{~S}$ ribosomal RNA targeted oligonucleotide probes.

\section{MATERIALS AND METHODS}

Animals and diets

Conventional (New Zealand White $\times$ Californian hybrid, strain INRA A1067) and specific pathogen-free rabbits (SPF, New Zealand White) were produced at the INRA Centers of Toulouse and Tours, France, respectively. The SPF rabbits were obtained and regularly controlled (microbiological analysis) free of coccidia, oxyuris, Pasteurella, Clostridium piliforme, Clostridium spiroforme, enteropathogenic Escherichia coli belonging to the serogroups $\mathrm{O}_{2}, \mathrm{O}_{15}, \mathrm{O}_{26}, \mathrm{O}_{49}, \mathrm{O}_{85}, \mathrm{O}_{103}, \mathrm{O}_{109}, \mathrm{O}_{128}$, and $\mathrm{O}_{132}$, rotavirus and calicivirus. They were reared in a highly protected environment - hygiene, prophylaxis, ventilation of superpressure air filtered at $10 \mu \mathrm{m}$, specific staff according to the methods described by Coudert et al. (14) - and no pathological problem has been observed since the creation of this animal colony in 1987. Conventional rabbits were housed in a closed building but in less strict conditions and no microbiological control was routinely carried out. They were all in apparently good health before the experiments. These animal models were chosen to determine the effect of the sanitary status and the breeding conditions on the modification of caecal flora.

Before weaning, litters and does were fed a commercial diet. From weaning (day 28) young rabbits were placed in separated rooms in individual wire cages (dimensions, $26 \times 33 \times 65 \mathrm{~cm}, 1 \times \mathrm{h} \times \mathrm{b})$ at room temperature $\left(18^{\circ} \pm\right.$ $2^{\circ} \mathrm{C}$ ) with feed boxes and water pipes, a 12:12 light:dark cycle (lights on 07:00 h), a relative humidity around $60 \%$, and a minimum of $0.8 \mathrm{~m}^{3}$ air changes per hour.

Conventional and SPF rabbits were divided into two groups. One group of conventional and one group of SPF were fed with a standard diet (diet S) containing 19\% of acid detergent fibre (ADF) corresponding to current recommendations (15). One group of conventional and one group of SPF rabbits received a low-fibre diet (diet D) containing only 9\% ADF. Wheat and dehydrated alfalfa meal were, respectively, the main source of starch and fibre. The chemical composition of diets S and D was, respectively ( $\%$ of dried matter): $15.9 \%$ and $17.7 \%$ crude protein, $16.2 \%$ and $7.2 \%$ crude fibre, $18.9 \%$ and $8.8 \%$ ADF, $9.6 \%$ and $32.0 \%$ starch, and $10.31 \mathrm{MJ}$ and $13.06 \mathrm{MJ}$ metabolic energy $/ \mathrm{kg}$ (13). Origin and proportions of fibre fractions (cellulose, hemicelluloses and pectins) were similar in both diets, as was the ratio of digestible protein/digestible energy. All the animals were fed ad libitum, and were able to modulate their feed intake according to the amount of energetic diet. No additive was included in the diet except an anticoccidian agent (Cycostat 65G; Alpharma, Verrières le Buisson, France).

Six healthy rabbits from each group were killed with a lethal injection of $5 \%$ Nesdonal solution (sodium thiopental, Merial, France) by intraperitoneal and intravenous injections (1.5 ml doses) at the ages of 18, 25, 28, 42 and 70 days for conventional rabbits and 28 and 70 days for SPF rabbits. The animals were killed between 13:00 and 16:00 h, without fasting. Just after euthanasia, 5-20 g of caecal content of each rabbit were collected, placed in vials and immediately freeze-dried.

\section{Nucleic acid extraction and hybridization}

DNA oligonucleotide probes complementary to regions of the SSU rRNA used in this study are described in Table I. Probes were synthesized by Eurogentec (Seraing, Belgium), and $5^{\prime}$ end-labelled with $\left[\gamma-{ }^{32} \mathrm{P}\right]$ ATP (Amersham Pharmacia Biotech, Saclay, France). Probes were purified on a G-50 sephadex column (Amersham Pharmacia Biotech) with a $1 \times$ Tris-EDTA solution as eluant. The quality of labelled probes was verified by electrophoresis on thinlayer (TLC plates, polyester polyethyleneimine cellulose, Sigma, St Louis, USA) and bicarbonate of ammonium 0.5 $\mathrm{M}$ as a mobile phase. Probes targeting Ruminococcus and Fibrobacter genera were chosen because these cellulolytic bacteria are the predominant species in the gastrointestinal tract of ruminant and some monogastric animals such as the horse (16), pig (17) and rat $(18,19)$. The Escherichia coli probe was used to detect and quantify the level of $E$. coli in healthy and diarrhoeic rabbits. Total nucleic acid was extracted from about $50 \mathrm{mg}$ of homogeneous lyophilized caecal sample after disruption of caecal cells 
Table I

Oligonucleotide probes and standard strains used in this study

\begin{tabular}{|c|c|c|c|c|}
\hline Probe $\left(5^{\prime}\right.$ to $\left.3^{\prime}\right)$ & Target & $\begin{array}{l}\text { Wash } \\
\text { temperature } \\
\left({ }^{\circ} \mathrm{C}\right)\end{array}$ & References & Standard organisms \\
\hline $\begin{array}{l}\text { ACG-GGC-GGT-GTG- } \\
\text { T(G/A)C }\end{array}$ & All organisms & 46 & $(41)$ & $\begin{array}{l}\text { 16S ribosomal RNA from E. coli } \\
\text { MRE } 600 \text { (Boëhringer Mannheim) }\end{array}$ \\
\hline $\begin{array}{l}\text { GCT-GCC-TCC-CGT- } \\
\text { AGG-AGT }\end{array}$ & All Eubacteria & 54 & $(23)$ & $\begin{array}{l}\text { 16S ribosomal RNA from E.coli } \\
\text { MRE } 600 \text { (Boëhringer Mannheim) }\end{array}$ \\
\hline $\begin{array}{l}\text { ACC-AGA-CTT-GCC- } \\
\text { CTC-C }\end{array}$ & All Eukarya & 54 & $(23)$ & Neocallimastix frontalis $\mathrm{MCH} 3$ \\
\hline $\begin{array}{l}\text { GTA-CAC-ACA-ATG- } \\
\text { AAG-TGC-ATA- } \\
\text { AAG-G }\end{array}$ & Anaerobic fungi & 47 & $(42)$ & Neocallimastix frontalis $\mathrm{MCH} 3$ \\
\hline $\begin{array}{l}\text { GTG-CTC-CCC-CGC- } \\
\text { CAA-TTC-CT }\end{array}$ & All Archaea & 50 & (23) & Methanococcus voltaea (DSM 7078) \\
\hline $\begin{array}{l}\text { GCA-CTT-AAG-CCG- } \\
\text { ACA-CCT }\end{array}$ & $\begin{array}{l}\text { Flexibacter- } \\
\text { Cytophaga- } \\
\text { Bacteroides group }\end{array}$ & 43 & $(43)$ & Bacteroides vulgatus (ATCC 4245) \\
\hline $\begin{array}{l}\text { TGC-CCC-TGA-ACT- } \\
\text { ATC-CAA-GA }\end{array}$ & F. succinogenes & 48 & $(23)$ & F. succinogenes S85 (ATCC 19169) \\
\hline $\begin{array}{l}\text { ACG-GTT-GTT-CCG- } \\
\text { GAA-TGC-GGG }\end{array}$ & $F$. intestinalis & 55 & $\begin{array}{l}\text { (44), modified } \\
\text { by Millet (unpublished } \\
\text { observations) }\end{array}$ & F. intestinalis NR9 (ATCC 43854) \\
\hline $\begin{array}{l}\text { GTC-ATG-CGG-CTT- } \\
\text { CGT-TAT }\end{array}$ & R. albus & 46 & $(45)$ & R. albus 7 (ATCC 27210) \\
\hline $\begin{array}{l}\text { TTC-TCT-TTG-TTA- } \\
\text { ATT-GCC-AT }\end{array}$ & R. flavefaciens & 45 & $(45)$ & $\begin{array}{l}\text { R. flavefaciens FD1 (Urbana } \\
\text { Champaign, USA) }\end{array}$ \\
\hline $\begin{array}{l}\text { CAA-GCT-TGC-CAG- } \\
\text { TAT-CAG-ATG }\end{array}$ & E. coli & 47 & $\begin{array}{l}\text { (L. Millet, unpublished } \\
\text { observations) }\end{array}$ & E. coli DH5-alpha \\
\hline $\begin{array}{l}\text { CCA-ACA-TCG-AAC- } \\
\text { TCA-CTC-AAG-AT }\end{array}$ & $\begin{array}{l}\text { Prevotella ruminicola } \\
\text { subsp. ruminicola }\end{array}$ & 54 & $(37)$ & Prevotella ruminicola (ATCC 19189) \\
\hline
\end{tabular}

with $0.3 \mathrm{~g}$ of $0.1-\mathrm{mm}$ zirconium beads in a Bead Beater (MM 2000, Kurt Retsch, Haam, Germany) (20, 21). The general procedure of isolation and quantification of total RNA was based on previously described methods (22-24). The RNA was extracted with chloroform and precipitated in a minimum of $30 \mathrm{~min}$ at $-20^{\circ} \mathrm{C}$ by addition of isopropanol. After centrifugation for $30 \mathrm{~min}$ (Eppendorf 5415C) at $14000 \mathrm{r} / \mathrm{min}$, RNA pellets were washed with $80 \%$ ethanol and resuspended in double-distilled water. The nucleic acid concentrations were measured spectrophotometrically assuming an optical density at $260 \mathrm{~nm}$ of 1 for $40 \mu \mathrm{g} / \mathrm{ml}$ (24). All materials and buffers were processed with diethylpyrocarbonate (Sigma), to minimize the degradation of nucleic acids by RNAase. The same protocol of extraction was applied to prepare reference RNA strains.

The total RNA was denatured by addition of $2 \%$ glutaraldehyde (Sigma) $(v / 3 v)$, and diluted to a final concentration of $10 \mathrm{ng} / \mu \mathrm{l}$. Diluted RNA was applied in triplicate to Hybond-N + charge membrane $(0.45 \mu \mathrm{m}$ diameter; Amersham Pharmacia Biotech) by a dot-blot device (BioDot, Bio-Rad, Marne la Coquette, France). Diluted RNA, which hybridized with probe must be situated between 25 and $100 \mathrm{ng} / \mu \mathrm{l}$ of concentration of rRNA. It must be contained in a quantity of total RNA varying between 5 and $2.5 \mu \mathrm{g} / \mu \mathrm{l}$.

RNA extracted from the standard organisms and $16 \mathrm{~S}$ rRNA from E. coli (Roche, Meylan, France) as reference were used to standardize the hybridization response (Table I). The membranes were air-dried and fixed by UV (120 mJ.cm ${ }^{-2}$ ) with a Spectrolinker XL 1000 UV (Spectronics Corporation, Lincoln, USA). These membranes were prehybridized for $1 \mathrm{~h}$ at $42^{\circ} \mathrm{C}$ with a hybridization buffer $(0.9$ $\mathrm{M} \mathrm{NaCl} ; 50$ mM NaPO$;$; $\mathrm{pH} 7.0 ; 5$ mM EDTA; pH 7.2; $10 \times$ Denhart's solution; $0.5 \mathrm{mg} / \mathrm{ml}$ of Poly $\mathrm{A}^{+}$and $0.5 \%$ of sodium dodecyl sulphate: SDS) in a hybridization bottle (Hybaid, Amersham). The membranes were hybridized in the same buffer with $2 \mu \mathrm{l} \mathrm{cm}{ }^{-2} \mathrm{cpm}$ of specific labelled oligonucleotide per sample dot for a minimum of $3 \mathrm{~h}$ at $42^{\circ} \mathrm{C}$, and washed with $1 \% \mathrm{SDS} / 1 \times \operatorname{SSC}(0.15 \mathrm{M} \mathrm{NaCl}+$ $0.15 \mathrm{M}$ trisodium citrate) solution at ambient temperature and $20 \mathrm{~min}$ at a previously determined wash temperatures (Tw) for each probe (Table I). Membranes were dried and exposed to a screen (Storm, Molecular Dynamics, Bondoufle, France). Bound probes were quantified by Image Quant soft-ware (Molecular Dynamics) and the relative abundance of Bacteria, Archaea and Eukarya domains were expressed as a percentage of the sum of bacterial, 
archaeal and eukaryal rRNAs. The proportion of specific bacteria was expressed as the percentage of the total bacterial rRNA.

\section{Statistical analysis}

All data were expressed as mean \pm standard error of the mean. The quantification of targeted rRNA $(\mu \mathrm{g})$ and their proportions (\%) in the samples were performed by analysis of variance using the GLM procedure of Statistical Analysis System (25). Bartlett's test was performed to analyse the homogeneity of variance. When the variances were heterogeneous, statistical analyses were performed on the $\log _{\mathrm{n}}$ transformed variables.

Data on caecal flora were analysed in accordance with the age, dietary fibre and health status. Microbial status was analysed in terms of interactions with age and dietary fibre. The effect of age was analysed only on rRNA from conventional and SPF rabbits fed standard diet (S).

\section{RESULTS}

Whatever the age, the microbial status or the health of the rabbits, no response was observed with probes targeting rRNA of anaerobic fungi, E. coli and P. ruminicola subsp. ruminicola. These micro-organisms are either absent from the caecal ecosystem or present in numbers too low to be detected by the probes, the limit of detection being approximately $10^{6}$ bacteria $\mathrm{g}^{-1}$ of caecal contents $(25 \mathrm{ng} / \mu \mathrm{l})$. The total quantity of rRNA found in each sample is expressed as the summation of bacterial, eukaryal and archaeal rRNA detected with the specific probes targeting these three domains, respectively. Quantification of microbial communities is expressed both in absolute $(\mu \mathrm{g} / 50 \mathrm{mg}$ of samples) and relative (\%) values. The relative abundance of each population is calculated as the percentage of specific rRNA to the total microbial rRNA for the eukarya, bacteria and archaea or to the total bacterial rRNA for the others. No-targeted bacteria were obtained by subtraction between rRNA of total bacteria and Flexibacter-Cytophaga-Bacteroides group plus cellulolytic bacteria.

\section{Maturation of the caecal microflora in healthy rabbits fed the standard diet}

Conventional rabbits (Table II). The total quantity of rRNA markedly increased from day 18 to day 25 ( $p<$ $0.001)$, then decreased slightly and stabilized. Bacterial rRNA also increased between day 18 and day 25 ( $p<$ 0.001 ), after weaning it represented $>80 \%$ of caecal rRNA. No eukaryal rRNA was detected at day 18 , its concentration increased until day 42 and decreased at day 70. Its percentage did not exceed $7 \%$ of total rRNA. Except on day 25, the archaeal rRNA concentration was quite stable but its percentage markedly decreased with the age of the animals $(p<0.001)$; after weaning the archaeal community represented between $7 \%$ and $12 \%$ of the total microflora. The size of the Flexibacter-Cytophaga-Bacteroides group decreased after weaning $(p<0.001)$. The cellulolytic community ( $R$. flavefaciens $+R$. albus $+F$. succinogenes $+F$. intestinalis) became established before weaning and its size increased after weaning $(p<0.01)$ but did not exceed $6.7 \%$ of the total bacterial community during this period. $R$. flavefaciens appeared to be the dominant cellulolytic species.

SPF rabbits (Table III). Except for the eukaryal community, which markedly decreased with the animal's age $(p<0.05)$, the microbial communities targeted in this study remained quite stable with the animal's age. Compared with conventional animals, SPF rabbits harboured a lower microbial community, as the total quantities of microbial and bacterial rRNA were twofold lower $(p<$ $0.01)$. In contrast, in the SPF rabbits the cellulolytic community represented a rather higher proportion of the total bacterial community $(p<0.05)$ at 28 and 70 days $(35.1 \%$ and $16.3 \%$, respectively) compared with conventional rabbits $(5.1 \%$ and $6.7 \%$, respectively). Also, $R$. albus was the dominant cellulolytic species, especially after weaning in SPF rabbits.

Effect of dietary fibre level on caecal microflora of healthy conventional and SPF rabbits (Tables II and III). Compared with the animals fed the standard diet, the caecal microbial community of the conventional rabbits fed the low fibre diet (diet D) was essentially characterized by a twofold lower archaeal community $(p<0.001)$ and higher populations of $R$. albus and of $F$. intestinalis which increased by a factor of 4 to $20(p<0.001)$ and by a factor of 3 respectively $(p<0.05)$.

In SPF rabbits, the consumption of the low fibre diet led to a significant decrease of the eukaryal community ( $p<$ $0.01)$ and of the $R$. albus population $(p<0.05)$. In contrast, the size of the $F$. succinogenes population was higher with the low fibre diet $(p<0.01)$.

\section{Caecal microflora of diarrhoeic conventional rabbits (Table} IV)

Disturbances in the caecal microflora of sick rabbits were estimated by comparing the sizes of the different microbial communities of sick rabbits with those of 42- and 70-dayold conventional healthy animals. The sick rabbits were between 41 and 63 days old.

All the microbial communities were affected by diarrhoea except the Flexibacter-Cytophaga-Bacteroides group and $R$. flavefaciens, which remained stable. Compared with healthy animals, the caecal microbial community of sick rabbits was characterized by a slight decrease in the proportion of total bacterial rRNA $(p<0.01)$, a marked decrease in $R$. albus and archaeal populations, moderate increase in the sizes of the eukaryal community and of the $F$. intestinalis population $(p<0.001)$ and by a strong increase $(\times 27)$ of the $F$. succinogenes population $(p<0.001)$. Globally the proportion of the cellulolytic 
Table II

Quantification and proportion of microbial $r R N A$ in caecal contents of healthy conventional rabbits, according to age and level of the fibre in diet $\dagger$

\begin{tabular}{|c|c|c|c|c|c|c|c|c|c|c|}
\hline & \multicolumn{7}{|l|}{ Age (days) } & \multicolumn{3}{|c|}{ Statistical level } \\
\hline & \multirow[t]{2}{*}{18} & \multirow[t]{2}{*}{25} & \multirow[t]{2}{*}{28} & \multicolumn{2}{|l|}{42} & \multicolumn{2}{|l|}{70} & \multirow[b]{2}{*}{ Age* } & \multirow[b]{2}{*}{ Diet } & \multirow[b]{2}{*}{$\mathrm{A} / \mathrm{D}^{\dagger}$} \\
\hline & & & & S diet & $\mathrm{D}$ diet & $\mathrm{S}$ diet & $\mathrm{D}$ diet & & & \\
\hline \multicolumn{11}{|c|}{ Total rRNA* } \\
\hline$(\mu \mathrm{g})$ & $39.3^{\mathrm{a}}(20.6)$ & $329.8^{\mathrm{b}}(202.6)$ & $111.6^{\mathrm{b}}(25.7)$ & $190.6^{\mathrm{b}}(73.9)$ & $135.5(19.2)$ & $148.8^{\mathrm{b}}(84.6)$ & $128.0(16.0)$ & $<0.001^{\S}$ & $\mathrm{NS}^{\S}$ & $\mathrm{NS}^{\S}$ \\
\hline \multicolumn{11}{|l|}{ Bacteria } \\
\hline$(\mu \mathrm{g})$ & $14.7^{\mathrm{a}}(12.4)$ & $242.5^{\mathrm{b}}(142.4)$ & $82.8^{\mathrm{b}}(33.0)$ & $164.6^{\mathrm{b}}(59.5)$ & $121.5(23.3)$ & $125.0^{\mathrm{b}}(78.3)$ & $106.5(22.3)$ & $<0.001^{\S}$ & $\mathrm{NS}^{\S}$ & $\mathrm{NS}^{\S}$ \\
\hline$(\%)^{\|}$ & $35.8^{\mathrm{a}}(26.5)$ & $75.2^{\mathrm{b}}(4.1)$ & $72.8^{\mathrm{b}}(17.0)$ & $87.0^{\mathrm{b}}(4.1)$ & $89.2(7.3)$ & $81.7^{\mathrm{b}}(5.9)$ & $82.5(8.0)$ & $<0.001^{\S}$ & NS & NS \\
\hline \multicolumn{11}{|l|}{ Eukarya } \\
\hline$(\mu \mathrm{g})$ & ND & $2.1(1.7)$ & $6.3(9.4)$ & $12.5(10.8)$ & $6.7(9.7)$ & $7.8(5.9)$ & $13.1(10.0)$ & NS & NS & 0.17 \\
\hline$(\%)^{\|}$ & ND & $0.5^{\mathrm{a}}(0.3)$ & $6.2^{\mathrm{ab}}(10.0)$ & $5.8^{\mathrm{ab}}(4.2)$ & $5.4(8.3)$ & $6.4^{\mathrm{b}}(5.4)$ & $11.0(8.9)$ & $0.047^{\S}$ & NS & NS \\
\hline \multicolumn{11}{|l|}{ Archaea } \\
\hline$(\mu \mathrm{g})$ & $24.7^{\mathrm{a}}(16.9)$ & $86.2^{\mathrm{b}}(60.8)$ & $23.5^{\mathrm{a}}(12.8)$ & $13.4^{\mathrm{a}}(6.1)$ & $7.1(2.5)$ & $16.2^{\mathrm{a}}(6.1)$ & $8.3^{\mathrm{b}}(2.5)$ & $<0.001$ & $<0.001^{\S}$ & NS \\
\hline$(\%)^{\|}$ & $64.2^{\mathrm{a}}(26.5)$ & $24.5^{\mathrm{b}}(4.1)$ & $22.0^{\mathrm{b}}(13.2)$ & $7.0^{\mathrm{b}}(1.0)$ & $5.2(1.4)$ & $12.1^{\mathrm{b}}(3.7)$ & $6.4^{\mathrm{b}}(1.4)$ & $<0.001$ & $<0.01^{\S}$ & $\mathrm{NS}^{\S £}$ \\
\hline \multicolumn{11}{|c|}{ Bacteroides** } \\
\hline$(\mu \mathrm{g})$ & ND & $115.7^{\mathrm{a}}(34.5)$ & $29.8^{\mathrm{b}}(20.8)$ & $28.2^{\mathrm{b}}(4.9)$ & $52.5(55.3)$ & $18.9^{\mathrm{b}}(10.3)$ & $45.0^{\mathrm{b}}(17.6)$ & $<0.001^{\S}$ & $\mathrm{NS}^{\S}$ & $\mathrm{NS}^{\S}$ \\
\hline$(\%)^{\#}$ & ND & $58.8^{\mathrm{a}}(28.9)$ & $42.0^{\mathrm{ab}}(30.1)$ & $18.1^{\mathrm{ab}}(4.1)$ & $42.8(43.4)$ & $17.0^{\mathrm{b}}(10.9)$ & $42.4^{\mathrm{b}}(21.2)$ & $0.012^{\S}$ & $0.085^{\S}$ & $\mathrm{NS}^{\S}$ \\
\hline \multicolumn{11}{|c|}{ F. succinogenes } \\
\hline$(\mu \mathrm{g})$ & $0.15(0.10)$ & $0.35(0.25)$ & $0.72(0.51)$ & $0.07(0.00)$ & $0.58(0.26)$ & $0.12(0.13)$ & $0.28(0.32)$ & $0.12^{\S}$ & $0.092^{\S}$ & $\mathrm{NS}^{\S}$ \\
\hline$(\%)^{\#}$ & $2.5^{\mathrm{a}}(2.12)$ & $0.1^{\mathrm{b}}(0.09)$ & $1.3^{\mathrm{ab}}(1.10)$ & $0.1^{\mathrm{b}}(0.02)$ & $0.5(0.17)$ & $0.2^{\mathrm{b}}(0.17)$ & $0.4(0.42)$ & 0.021 & $0.11^{\S}$ & $\mathrm{NS}^{\S}$ \\
\hline \multicolumn{11}{|c|}{ F. intestinalis } \\
\hline$(\mu \mathrm{g})$ & ND & ND & $0.48(0.11)$ & $0.28(0.09)$ & $0.90(0.87)$ & $0.70(0.92)$ & $2.04(2.98)$ & NS & $0.012^{\S}$ & $\mathrm{NS}^{\S}$ \\
\hline$(\%)^{\#}$ & ND & ND & $0.5^{\mathrm{b}}(0.03)$ & $0.2^{\mathrm{b}}(0.13)$ & $0.8(0.75)$ & $0.5^{\mathrm{b}}(0.42)$ & $1.9(1.49)$ & NS & $<0.01^{\S}$ & $\mathrm{NS}^{\S}$ \\
\hline \multicolumn{11}{|c|}{ R. flavefaciens } \\
\hline$(\mu \mathrm{g})$ & $0.15^{\mathrm{a}}(0.10)$ & $1.33^{\mathrm{b}}(1.21)$ & $2.52^{\mathrm{bc}}(1.20)$ & $3.74^{\mathrm{bc}}(0.83)$ & $4.0(2.0)$ & $6.30^{\mathrm{c}}(3.20)$ & $4.61(4.65)$ & $<0.001^{\S}$ & $\mathrm{NS}^{\S}$ & $\mathrm{NS}^{\S}$ \\
\hline$(\%)^{\#}$ & $2.5^{\mathrm{ab}}(2.1)$ & $0.5^{\mathrm{a}}(0.3)$ & $3.5^{\mathrm{b}}(1.8)$ & $2.8^{\mathrm{b}}(0.8)$ & $3.1(1.4)$ & $6.8^{\mathrm{b}}(3.6)$ & $4.9(6.03)$ & $<0.01^{\S}$ & NS & $\mathrm{NS}^{\S}$ \\
\hline \multicolumn{11}{|l|}{ R. albus } \\
\hline$(\mu \mathrm{g})$ & $0.1(0.07)$ & $0.7(0.18)$ & $0.6(1.02)$ & $0.1(0.03)$ & $1.4(0.9)$ & $0.6(0.49)$ & $2.0(0.75)$ & NS & $<0.001^{\S}$ & $0.15^{\S}$ \\
\hline$(\%)^{\#}$ & $1.5^{\mathrm{a}}(1.11)$ & $0.4^{b}(0.26)$ & $0.6^{\mathrm{ab}}(0.70)$ & $0.1^{\mathrm{b}}(0.02)$ & $1.1(0.8)$ & $0.6^{\mathrm{ab}}(0.50)$ & $2.0(0.80)$ & 0.0129 & $<0.01^{\S}$ & $0.02^{\S}$ \\
\hline
\end{tabular}

Data are means \pm standard errors of the means in parentheses ( $n=6$ samples per treatment). rRNA was extracted from $50 \mathrm{mg}$ of lyophilized caecal content. S diet, standard diet; D diet, fibre-deficient diet; ND, inferior to the level of the detection $(<25 \mathrm{ng} / \mu 1$ hybridized rRNA $)$; NS, not significant.

* Statistical analysis performed between 18 and 70 days on rabbits fed standard diet.

${ }^{\dagger}$ Statistical analysis performed between diet and age at 42 and 70 days. a, b, means values, between ages, with common superscript were not significantly different at the level $p=0.05$.

${ }^{*}$ Total rRNA is the sum of bacterial, eukaryal and archaeal rRNA.

${ }^{\S}$ Statistics were performed on $\log _{\mathrm{n}}$ transformed variable, when the variance was not homogeneous (Bartlett's test).

$\|$ Expressed to the $\%$ of the total rRNA.

\#Expressed to the $\%$ of the total bacterial rRNA.

**Include Flexibacter-Cytophaga-Bacteroides group.

community was twofold higher in sick animals. No Clostridium spiriforme was observed after Gram's staining of the samples.

\section{DISCUSSION}

Methodological aspect

The most basic prerequisites for ecological studies are identification and enumeration of community members. Indirect microbiological techniques such as selective en- richments, pure culture isolation and most-probable-number estimates have been used. However, the limitation of these techniques was their inability to detect adequately all community members. Molecular ecological methods such as PCR (polymerase chain reaction), DGGE (denaturing gradient gel electrophoresis), TGGE (temperature gradient gel electrophoresis), SSCP (single-strand conformation polymorphisms) and dot-blot hybridization with $16 \mathrm{~S}$ rRNA targeted oligonucleotide probes are now used exten- 
Table III

Quantification and proportion of microbial $r R N A$ in caecal contents of healthy SPF rabbits, according to the age and the level of fibre in the diet

\begin{tabular}{|c|c|c|c|c|c|}
\hline & \multicolumn{3}{|l|}{ Age (days) } & \multicolumn{2}{|c|}{ Statistical level } \\
\hline & \multirow[t]{2}{*}{28} & \multicolumn{2}{|l|}{70} & \multirow[t]{2}{*}{ Age* } & \multirow[t]{2}{*}{ Diet } \\
\hline & & $\mathrm{S}$ diet & 'diet & & \\
\hline $\begin{array}{c}\text { Total rR } \\
(\mu \mathrm{g})\end{array}$ & $86.0(39.0)$ & $60.7(25.7)$ & $83.3(26.2)$ & NS & NS \\
\hline $\begin{array}{c}\text { Bacteria } \\
(\mu \mathrm{g}) \\
(\%)^{\|}\end{array}$ & $\begin{array}{l}54.2(31.8) \\
65.4(23.2)\end{array}$ & $\begin{array}{l}51.0(26.2) \\
82.2(7.6)\end{array}$ & $\begin{array}{l}78.4(20.9) \\
93.5(4.1)\end{array}$ & $\begin{array}{l}0.55 \\
0.02\end{array}$ & $\begin{array}{l}\quad 0.09 \\
\text { NS }\end{array}$ \\
\hline $\begin{array}{c}\text { Eukarya } \\
(\mu \mathrm{g}) \\
(\%)^{\|}\end{array}$ & $\begin{array}{l}28.4(27.1) \\
35.7(28.4)\end{array}$ & $\begin{array}{l}4.7(1.7) \\
8.6(4.0)\end{array}$ & $\begin{array}{l}0.73(0.32) \\
1.0(0.3)\end{array}$ & $\begin{array}{l}0.012^{\S} \\
0.02^{\S}\end{array}$ & $\begin{array}{l}<0.01 \\
<0.001^{\S}\end{array}$ \\
\hline $\begin{array}{c}\text { Archaea } \\
(\mu \mathrm{g}) \\
(\%)^{\|}\end{array}$ & $\begin{array}{l}4.0(0.9) \\
6.5(4.1)\end{array}$ & $\begin{array}{l}5.1(1.6) \\
9.4(3.9)\end{array}$ & $\begin{array}{l}6.7(2.1) \\
7.5(2.2)\end{array}$ & $\begin{array}{l}0.08 \\
\mathrm{NS}^{\S}\end{array}$ & $\begin{array}{l}\text { NS } \\
\text { NS }\end{array}$ \\
\hline $\begin{array}{c}\text { Bacteroic } \\
(\mu \mathrm{g}) \\
(\%)^{\#}\end{array}$ & $\begin{array}{r}38.0(-) \\
105.5(-)\end{array}$ & $\begin{array}{l}27.7(21.8) \\
49.7(20.7)\end{array}$ & $\begin{array}{l}67.0(-) \\
62.6(-)\end{array}$ & $\begin{array}{l}\mathrm{NS} \\
0.061\end{array}$ & $\begin{array}{l}\text { NS } \\
\text { NS }\end{array}$ \\
\hline $\begin{array}{c}F . \text { succin } \\
(\mu \mathrm{g}) \\
(\%)^{\#}\end{array}$ & $\begin{array}{l}0.37(0.31) \\
1.5(1.50)\end{array}$ & $\begin{array}{l}0.29(0.13) \\
0.8(0.30)\end{array}$ & $\begin{array}{l}1.21(0.23) \\
1.6(0.40)\end{array}$ & $\begin{array}{l}0.058 \\
\mathrm{NS}\end{array}$ & $\begin{array}{r}<0.01 \\
0.02\end{array}$ \\
\hline $\begin{array}{c}F \text {. intest } \\
(\mu \mathrm{g}) \\
(\%)^{\#}\end{array}$ & $\begin{array}{l}2.70(0.70) \\
9.9(9.50)\end{array}$ & $\begin{array}{l}1.40(0.61) \\
3.9(3.48)\end{array}$ & $\begin{array}{l}1.53(1.46) \\
2.4(2.69)\end{array}$ & $\begin{array}{l}0.082 \\
0.056^{\S}\end{array}$ & $\begin{array}{l}\text { NS } \\
\text { NS }\end{array}$ \\
\hline $\begin{array}{l}\text { R. flavef } \\
(\mu \mathrm{g}) \\
(\%)^{\#}\end{array}$ & $\begin{array}{r}3.97(1.50) \\
12.7(9.58)\end{array}$ & $\begin{array}{l}2.13(1.51) \\
5.5(4.41)\end{array}$ & $\begin{array}{l}3.14(1.48) \\
4.3(2.27)\end{array}$ & $\begin{array}{l}0.09 \\
0.03^{\S}\end{array}$ & $\begin{array}{l}\text { NS } \\
\text { NS }\end{array}$ \\
\hline $\begin{array}{c}\text { R. albus } \\
(\mu \mathrm{g}) \\
(\%)^{\#}\end{array}$ & $\begin{array}{r}5.05(3.57) \\
14.3(13.45)\end{array}$ & $\begin{array}{r}6.08(3.14) \\
16.9(12.35)\end{array}$ & $\begin{array}{l}1.18(0.99) \\
1.5(1.05)\end{array}$ & $\begin{array}{l}\text { NS } \\
\text { NS }\end{array}$ & $\begin{array}{l}0.015 \\
0.012^{\S}\end{array}$ \\
\hline
\end{tabular}

For explanation see footnote to Table II; except *statistical analysis was performed between 28 and 70 days on rabbits fed standard diet.

sively to assess the microbial community structure in various complex microbial environments. However, only molecular hybridization techniques such as dot-blot hybridization with $16 \mathrm{~S}$ rRNA targeted oligonucleotide probes allow simultaneous identification and quantification of microbial populations in various complex microbial environments such as aquatic sediments (26), anaerobic digesters (24) and the gastrointestinal ecosystem of animals (27-29). Nevertheless, this microbial approach had limits, such as the level of detection being approximately $10^{6}$ bacteria $\mathrm{g}^{-1}$ of caecal contents ( $25 \mathrm{ng}$ of $\left.\mathrm{rRNA} / \mu \mathrm{l}\right)$, and a moderate yield of extraction of RNA. However, to our knowledge, the rabbit digestive microbial ecosystem had not been analysed previously by this molecular approach. In consequence, our work is the first study of the rabbit digestive microflora by a molecular ecological method. Dot-blot hybridization with oligonucleotide probes target- ing 16S rRNA appears to be a powerful and well adapted tool for analysing the specific microbial population according to ecological factors (age, diet, etc.).

A universal probe (S-*-Univ-1392-a-A15) was used to standardize the response obtained with specific probes. However, hybridization responses with a universal probe were generally two or three times lower than responses obtained with the eubacterial probe, even when the same reference organisms were used to compare these two probes. Raskin et al. (28) have also observed that the hybridization response with a universal probe was lower than the sum of the signals obtained with probes targeting the three domains (Bacteria, Archaea, Eukarya). They suggested that this may be caused mainly by a partial degradation of RNA. The underestimation of the universal probe response might also have been caused by a contamination of RNA by an inhibiting factor such as protein 
Table IV

Comparison of the caecal microflora of healthy and diarrhoeic conventional rabbits

\begin{tabular}{|c|c|c|c|}
\hline & \multicolumn{2}{|l|}{ Health status } & \multirow{2}{*}{$\begin{array}{l}\text { Statistical } \\
\text { level }\end{array}$} \\
\hline & $\begin{array}{l}\text { Health } \\
\text { (42 and } 70 \text { days) }\end{array}$ & $\begin{array}{l}\text { Sick } \\
\text { (41 to } 63 \text { days) }\end{array}$ & \\
\hline \multicolumn{4}{|c|}{ Total rRNA } \\
\hline$(\mu \mathrm{g})$ & $149.0(57.7)$ & $186.5(99.0)$ & $\mathrm{NS}^{\S}$ \\
\hline \multicolumn{4}{|l|}{ Bacteria } \\
\hline$(\mu \mathrm{g})$ & $127.9(52.1)$ & $114.7(43.8)$ & $\begin{array}{r}0.07^{\S} \\
-0.01 \S\end{array}$ \\
\hline & $85.0(6.9)$ & $69.5(20.8)$ & $<0.01^{\S}$ \\
\hline \multicolumn{4}{|l|}{ Eukarya } \\
\hline$(\mu \mathrm{g})$ & $9.9(9.0)$ & $69.5(84.2)$ & $<0.001^{\S}$ \\
\hline$(\%)^{\|}$ & $7.2(7.0)$ & $29.2(21.1)$ & $<0.001^{\S}$ \\
\hline \multicolumn{4}{|l|}{ Archaea } \\
\hline$(\mu \mathrm{g})$ & $11.1(5.7)$ & $2.0(0.6)$ & $<0.001^{\S}$ \\
\hline & $7.7(3.4)$ & $1.3(0.8)$ & $<0.001^{8}$ \\
\hline \multicolumn{4}{|c|}{ Bacteroides** } \\
\hline$(\mu \mathrm{g})$ & $33.9(28.0)$ & $48.4(32.5)$ & $\mathrm{NS}^{\S}$ \\
\hline$(\%)^{\#}$ & $27.4(25.3)$ & $40.9(27.7)$ & $0.04^{\S}$ \\
\hline \multicolumn{4}{|c|}{ F. succinogenes } \\
\hline$(\mu \mathrm{g})$ & $0.27(0.28)$ & $7.42(4.77)$ & $<0.001^{\S}$ \\
\hline$(\%)^{\#}$ & $0.3(0.26)$ & $7.7(3.35)$ & $<0.01^{\S}$ \\
\hline \multicolumn{4}{|c|}{$F$. intestinalis } \\
\hline$(\mu \mathrm{g})$ & $0.98(1.25)$ & $4.58(2.49)$ & $<0.001^{\S}$ \\
\hline$(\%)^{\#}$ & $0.8(1.00)$ & $4.3(2.80)$ & $<0.001^{\S}$ \\
\hline \multicolumn{4}{|c|}{ R. flavefaciens } \\
\hline$(\mu \mathrm{g})$ & $4.28(2.53)$ & $3.37(2.01)$ & NS \\
\hline$(\%)^{\#}$ & $3.9(2.77)$ & $3.7(3.57)$ & $\mathrm{NS}^{\S}$ \\
\hline \multicolumn{4}{|l|}{ R. albus } \\
\hline$(\mu \mathrm{g})$ & $1.10(0.97)$ & $0.15(0.09)$ & $<0.001^{\S}$ \\
\hline$(\%) \#$ & $1.0(0.92)$ & $0.1(0.10)$ & $<0.01^{\S}$ \\
\hline
\end{tabular}

For explanation, see footnotes to Table II.

molecules which prevent the caecal ecosystem affecting the hybridization between the universal probe and the sample rRNA. According to Raskin et al. (28), while cases of RNA degradation have been rare, their occasional occurrence underscores the importance of care when handling environmental samples and RNA extracts. Therefore, we have expressed total rRNA as the summation of bacterial, eukaryal and archaeal rRNA. Lin et al. (30) reported that for most bovine, ovine, caprine and swine rRNA samples from the gastrointestinal tract, the summations of the three individual domain contributions were relatively close to $100 \%$ (between $75 \%$ and $125 \%$ ). L. Millet (unpublished observations) has also observed a good correlation $\left(\mathrm{R}^{2}=0.88\right)$ between rRNA from rumen samples detected by universal probe and the sum of rRNA detected by eubacterial, eukaryal and archaeal probes.

\section{Caecal flora of conventional rabbits}

In our study, the bacterial community increased with the age and stabilized around weaning. These results are in agreement with those of Gouet and Fonty (5) and Padilha et al. (31). These authors have shown that the caecum of rabbits is colonized by an abundant anaerobic microflora $\left(10^{8}-10^{9}\right.$ bacteria $\left.\mathrm{g}^{-1}\right)$ during the first week after birth. This microflora stabilizes at around $10^{9}-10^{10}$ bacteria $\mathrm{g}^{-1}$ after weaning.

Eukaryal rRNA was at a low level or absent during the suckling period and represented $<7 \%$ of total rRNA after weaning. The origin of eukaryal rRNA in our samples was not determined, it probably originated from plant material, endogenous cells, yeast or protozoa, as anaerobic fungi were absent. Few authors have indicated the presence of other eukarya such as the yeast Saccharomycopsis guttulata (32) and ciliate protozoa (33). The dominance of the Flexibacter-Cytophaga-Bacteriodes group was in concordance with data reported by Gouet and Fonty (5) who observed with classical culture-based techniques the predominance of the Bacteroides genus in several parts of the rabbit digestive tract. The present study is the first demonstration of the presence of these four cellulolytic bacterial species (F. succinogenes, $F$. intestinalis, R. flavefaciens and $R$. albus) in the rabbit caecal content with molecular probes. These results contrast with those obtained by Boulharouf et al. (9) who have identified Eubacterium cellulosolvens and Bacteroides spp. as the predominant species in the young rabbit digestive tract. However, as the strains of Bacteroides spp. isolated by these authors were only characterized on the base of phenotypic criteria, they might be closely related to $\mathrm{Fi}$ brobacter species. These four species appear well adapted to the digestive biotopes as they have been detected in the gut of various animals. $F$. succinogenes, $R$. albus and $R$. flavefaciens are the dominant bacterial cellulolytic species in the rumen (34), and are also present in the caecum of pigs (17), equids (16) and the rat (19). The presence of cellulolytic bacteria at 18 days of age confirms the results of Boulharouf et al. (9), who observed that the establishment of these bacteria in the rabbit's digestive tract takes place approximately 2 weeks after birth. The proportion of the cellulolytic community (approximately $5 \%$ of the caecal microbial community after weaning) is comparable to those found in other animals, but the high proportion of archaea in our suckling animals contrasts with the results of Piattoni et al. (35) who noted the absence of methanogenesis during this period. These authors observed that reductive acetogenesis is a major characteristic of caecal fermentation in pre-weaned rabbits and that acetogenesis is replaced gradually and partially by methanogenesis with the increasing intake of solid feed. This percentage of archaeal rRNA is also higher than that generally reported for other young 
animals. In weaned rabbits, the archaeal community decreased markedly but remained at a quite high level compared with other mammals. In the rumen, for example, the proportion of this community does not generally exceed $2 \%$ of the total microbial community (36).

The absence of detection of $E$. coli is in agreement with data published by Gouet and Fonty (5) and Padilha et al. (31), who found that this species is usually at a very low level $\left(<10^{4}\right.$ bacteria $\mathrm{g}^{-1}$ ) or even absent in the rabbit digestive tract. The absence of anaerobic fungi also appears to be in agreement with previous observations by Fonty (unpublished observations) who did not find these micro-organisms by microscopic observations and culture-based techniques. In contrast, the absence of $P$. ruminicola is surprising because this species is very common in the animal digestive tract (34) and has already been found in the dominant flora of the rabbit (9). The failure of detection was probably due to the great genetic diversity of this species (37) and in consequence to the too great specificity of the probe, which appears to be restricted to the ruminal strains.

\section{Caecal microflora of SPF rabbits}

The smaller size of the bacterial community in SPF than in conventional rabbits is in accordance with the specific hygienic and health status of SPF-bred rabbits, which are maintained in a controlled and protected environment (14). It is also in accordance with the low fermentative activity exhibited by these animals (data not shown). The higher proportions of cellulolytic populations ( $F$. intestinalis and $R$. albus) and Flexibacter-Cytophaga-Bacteroides group in SPF than in conventional rabbits characterized a different balance in the bacterial communities in the two types of animals. It suggested that the higher resistance of SPF rabbits to digestive problems caused by fibre deficiency (13) would originate in a better balance of the caecal ecosystem in favour of commensal fibrolytic populations. The latter could also produce a greater barrier effect against potential pathogenic agents. Our results contrasted with those of Padilha et al. (31), who noticed a very low level $\left(10^{3}\right.$ bacteria $\left.\mathrm{g}^{-1}\right)$ of cellulolytic bacteria in SPF rabbits, using classical microbiology techniques. However, it is known that genetics may influence the composition of the intestinal flora. No study dealing with this effect has been carried out in rabbits. Moreover, in our study, the two types of rabbits were genetically close. SPF rabbits were New Zealand White strain, and conventional rabbits were New Zealand White $\times$ Californian hybrids. In consequence, the effect of genetics cannot explain the differences in the microflora composition between SPF and conventional animals. If this effect exists, it is less important than the microbial status of the rabbits, which includes the influence of breeding conditions.

\section{Impact of diet on caecal microflora}

The influence of diet on the digestive microflora has been studied in various animal species such as pigs (17), mice $(38,39)$ and rabbits $(10)$. The effect of the level of dietary fibre on the cellulolytic bacterial population is often controversial. In addition to differences due to the microbiological methods used in these studies, these controversial results are also probably related to differences in quantity and origins of plant fibre included in the diet.

The health status of the rabbits was much better with the standard diet than with the low fibre diet (13). The mortality and the Health Risk Index (HRI = mortality + morbidity rate) reached $28 \%$ and $78 \%$, respectively, with a fibre-deficient diet compared with $29 \%$ and $55 \%$ with a standard diet. The digestive disturbances appeared mainly between 28 and 42 days in the SPF group and during the period 43-56 days in the conventional animals.

Diarrhoea was the most common symptom of the sick rabbits and the major digestive lesions were the dilatation of the caeco-colic segment and a watery intestinal and caecal digesta. In addition, digestive lesions were similar regardless of microbial status and diet. In healthy animals, the balance between the different microbial communities was quite similar with the two diets. In SPF rabbits, the major change was an important decrease in the size of the eukaryal community. In conventional animals, a dietary fibre deficiency affected essentially the archaeal community and $R$. albus population. The decrease in the size of the archaeal community was in accordance with observations made in other digestive ecosystems. Usually, methane production is higher with high fibre diets than with a low fibre diet because fibre degradation leads to the production of hydrogen which is then used by the methanogens to reduce $\mathrm{CO}_{2}$ into methane $(27,40), R$. flavefaciens and $R$. albus being the main cellulolytic hydrogen-producing bacterial species. In contrast, in SPF rabbits the size of this community was similar with all diets. In this case, we can imagine competition between the methanogenic archaea and other hydrogenotrophic bacteria, especially the acetogenic species which appear to be the major hydrogenotrophic bacteria in the young rabbit caecum (35). In contrast to that observed by Boulharouf et al. (9) who noted that the level of cellulolytic bacteria increased 10 -fold when the percentage of crude fibre in the diet increased from $11 \%$ to $17 \%$, the size of the cellulolytic bacterial community (sum of the four species) remained approximately the same.

In contrast, the caecal microflora of the sick conventional rabbits (conventional and SPF) was markedly different from that of healthy conventional animals, all the microbial populations studied were affected except those of $R$. flavefaciens and the Flexibacter-Cytophaga-Bacteroides group. The decrease in these populations was probably linked to the reduction of the quality energy sources, because sick rabbits reduced or stopped their feed 
intake. E. coli and Clostridium spp. are the two potential pathogenic bacteria frequently present in diarrhoeic rabbits (32). We detected E. coli in only two samples from 20 diarrhoeic rabbits. In addition, this bacterium was only at the detection level of the probe ( $<25 \mathrm{ng} / \mu \mathrm{l}$ of rRNA). In the sick animals, the high level of eukaryal rRNA suggested a proliferation of eukaryote micro-organisms. In our animals, as a coccidiostatic was added to the diet, we can exclude the presence of coccidies. Lelkes and Chang (33) noticed the absence of protozoa in enteric disease but Peeters (32) detected coccidiosis in $41 \%$ and Saccharomyces guttulata in $28.4 \%$ of diarrhoeic rabbits. This yeast was considered part of the normal intestinal flora of weaned rabbits and experimental infections of rabbits with large numbers of blastospores did not induce any clinical signs. However, it was not excluded that abundant growth of $S$. guttulata in rabbits affected by intestinal disorders might aggravate enteric disease. Concurrently, a high level of eukaryotic rRNA would also contribute to an abnormal desquamation of epithelial cells of the gastrointestinal tract in the unhealthy animal. Moreover, this degradation of intestinal cells releases endogenous nuclease activity which would also affect the stability of RNA.

\section{CONCLUSION}

In conclusion, in addition to previously published observations (13), this study demonstrates the role of dietary fibre in the balance of the caecal microbial communities and confirms that a minimum level of fibre in the diet is necessary to maintain the stability (and the efficiency) of the caecal ecosystem. It is also the first demonstration of the presence of the four cellulolytic bacterial species $(R$. flavefaciens, $R$. albus, F. succinogenes and F. intestinalis), and an abundance of archaeal population in the rabbit gut and another confirmation of the ability of these species to live in the mammalian digestive tract. SPF rabbits appear to be less sensitive to the effect of the dietary fibre level than conventional rabbits.

\section{ACKNOWLEDGEMENTS}

The authors thank G. Andant (Laboratoire de Microbiologie, INRA, CR Clermont-Ferrand), P. Aymard and M. Segura (INRA, Station de Recherches Cunicoles), B. Sewald, M. Dupuy and J.P. Molteni (INRA, Pathologie Aviaire et Parasitologie) for their excellent technical assistance and F. Durand-Chaucheyras (Laboratoire de Microbiologie, INRA, CR Clermont-Ferrand and LALLEMAND Animal Nutrition) for her helpful advice during the experiment.

\section{REFERENCES}

1. Guerder F. RENALAP: la marge économique dégagée par le lapin s'améliore. Cuniculture 2000; 153: 105-13.

2. Licois D, Guillot JF, Mouline C, Reynaud A. Susceptibility of the rabbit to an enteropathogenic strain of Escherichia coli O103: effect of animals' age. Ann Rech Vet 1992; 23: $225-$ 32.
3. Lelkes L. A review of rabbit enteric-diseases: a new perspective. J Appl Rabbit Res 1987; 10: 55-61.

4. Gidenne T. Caeco-colic digestion in the growing rabbit: impact of nutritional factors and related disturbances. Livest Prod Sci 1997; 51: 73-88.

5. Gouet P, Fonty G. Changes in the digestive microflora of holoxenic rabbits from birth until adulthood. Ann Biol Anim Biochem Biophys 1979; 19: 553-66.

6. Padilha MTS, Licois D, Gidenne T, Carré B. Caecal microflora and fermentation pattern in exclusively milk-fed young rabbits. Reprod Nutr Dev 1999; 39: 223-30.

7. Emaldi O, Crociani F, Matteuzzi D. A note on the total viable counts and selective enumeration of anaerobic bacteria in the caecal content, soft and hard faeces of rabbit. J Appl Bacteriol 1979; 46: 169-72.

8. Davies ME. Cellulolytic bacteria in some ruminants and herbivores as shown by fluorescent antibody. J Gen Microbiol 1965; 39: 139-41.

9. Boulahrouf A, Fonty G, Gouet P. Establishment, counts and identification of the fibrolytic bacteria in the digestive tract of rabbit. Influence of feed cellulose content. Curr Microbiol 1991; 22: 1-25.

10. Fonty G, Gouet P, Riou Y. Effect of milk composition on the gastrointestinal microflora of artificially reared young rabbits. Ann Biol Anim Biochem Biophys 1979; 19: 567-71.

11. Prohaszka L, Szemeredi G. Regulation of the metabolism of volatile fatty acids in the caecum of rabbits. Zentralbl Veterinärmed 1984; 31: 358-66.

12. Licois $\mathrm{D}$, Coudert $\mathrm{P}$. Le point des recherches sur l'entérocolite épizootique du lapin. In: 8ème Journées de la Recherche Cunicole. Juin: Paris, France, 1999: 33-6.

13. Bennegadi N, Gidenne T, Licois D. Impact of fibre deficiency and sanitary status on non-specific enteropathy of the growing rabbit. Anim Res 2001; 50: 401-13.

14. Coudert P, Licois D, Besnard J. Establishment of a specified pathogen free breeding colony (SPF) without hysterectomy and hand-rearing procedures. In: 4th Congress WRSA. Budapest, Hungary, vol. 2, October, 1988: 137-48.

15. Gidenne T. Recent advances in rabbits nutrition: emphasis on fibre requirement. A review. World Rabbits Sci 2000; 8: $23-32$.

16. Julliand V, De Vaux A, Millet L, Fonty G. Identification of Ruminococcus flavefaciens as the predominant celullolytic bacterial species of the equine cecum. Appl Environ Microbiol 1999; 65: 3738-41.

17. Varel VH, Fryda SJ, Robinson IM. Cellulolytic bacteria from pig large intestine. Appl Environ Microbiol 1984; 47: 219-21.

18. Macy JM, Farrand JR, Montgomery L. Cellulolytic and non-cellulolytic bacteria in rat gastrointestinal tracts. Appl Environ Microbiol 1982; 44: 1428-34.

19. Montgomery L, Macy JM. Characterization of rat cecum cellulolytic bacteria. Appl Environ Microbiol 1982; 44: 143543.

20. Chomczynski P, Sacchi N. Single-step method of RNA isolation by acid guanidium thiocyanate-phenol-chloroform extraction. Anal Biochem 1987; 162: 156-9.

21. Faichney GJ, Poncet C, Lassalas B, Jouany JP, Millet L, Doré J, Brownlee AG. Effect of concentrates in a hay diet on the contribution of anaerobic fungi, protozoa and bacteria to nitrogen in rumen and duodenal digesta in sheep. Anim Feed Sci Technol 1997; 64: 193-213.

22. Stahl D, Flesher B, Mansfield H, Montgomery L. Use of phylogenetically based hybridization probes for studies of ruminal microbial ecology. Appl Environ Microbiol 1988; 54: 1079-84. 
23. Amann RI, Binder BJ, Olson RJ, Chisholm SW, Devereux R, Stahl DA. Combination of 16S rRNA-targeted oligonucleotide probes with flow cytometry for analyzing mixed microbial populations. Appl Environ Microbiol 1990; 56: 1919-25.

24. Raskin L, Poulsen LK, Nouguera DR, Rittmann BE, Stahl DA. Quantification of methanogenic groups in anaerobic biological reactors by oligonucleotide probe hybridization. Appl Environ Microbiol 1994; 60: 1241-8.

25. SAS I, Inc. SAS/STAT. Guide for personal computers, version 6.03 Edition SAS (Statistical Analysis System) Institute Inc., Cary, NC, 1988: 1028 pp.

26. Purdy KJ, Nedwell DB, Embley TM, Takii S. Use of $16 \mathrm{~S}$ rRNA oligonucleotide probes to investigate the occurrence and selection of sulfate-reducing bacteria in response to nutrient addition to sediment slurry microsomes from Japanese estuary. FEMS Microbiol Ecol 1997; 24: 221-34.

27. Van Nevel CJ, Demeyer DI. Control of rumen methanogenesis. Environ Monit Assess 1996; 42: 99-112.

28. Raskin L, Capman WC, Sharp R, Poulsen LK, Stahl D. Molecular ecology of gastrointestinal ecosystems. In: Makie RL, White BA, Issacson RE, eds. Gastrointestinal Microbiology, vol. 2. USA: Chapman and Hall, 1997: 243-98.

29. Sghir A, Gramet G, Suau A, Rochet V, Pochart P, Doré J. Quantification of bacterial groups within human fecal flora by oligonucleotide probe hybridization. Appl Environ Microbiol 2000; 66: 2263-6.

30. Lin C, Raskin L, Stahl D. Microbial community structure in gastrointestinal tracts of domestic animals: comparative analyses using rRNA-targeted oligonucleotide probes. FEMS Microbiol Ecol 1997; 22: 281-94.

31. Padilha MTS, Licois D, Gidenne T, Carré B, Fonty G. Relationships between microflora and caecal fermentation in rabbits before and after weaning. Reprod Nutr Dev 1995; 35: 375-86.

32. Peeters JE. Ethiology and pathology of diarrhoea in weaning rabbits. In: Auxilia T, ed. Rabbit Production Systems Including Welfare. Report no. EUR10983: Commission of the European Communities, 1987: 127-37.

33. Lelkes L, Chang C. Microbial dysbiosis in rabbit mucoid enteropathy. Lab Anim Sci 1987; 37: 757-64.

34. Stewart CS, Flint HJ, Bryant MP. The rumen bacteria. In: Hobson PN, Stewart SC, eds. The Rumen Microbial Ecosys- tem. London: Blackie Academic and Professional, 1997: 1072.

35. Piattoni F, Maertens L, Demeyer D. In vitro study of the age-dependent caecal fermentation pattern and methanogenesis in young rabbits. Reprod Nutr Dev 1996; 36: 253-61.

36. Morvan B, Doré J, Rieu-Lesme F, Foveat L, Fonty G, Gouet $P$. Establisment of hydrogen-utilizing bacteria in the rumen of newborn lambs. FEMS Microbiol Lett 1995; 117: 249-56.

37. Avgustin G, Wright F, Flint HJ. Genetic diversity and phylogenetic relationships among strains of Prevotella (Bacteroides) ruminicola from the rumen. Int J Syst Bacteriol 1994; 44: 246-55.

38. Brockett M, Tannock GW. Dietary influence on microbial activities in the caecum of mice. Can J Microbiol 1982; 28: 493-9.

39. Boulahrouf A, Fonty G, Gouet P. Establishment of cellulolytic bacteria in the digestive tract of conventionally reared young mice: effect of the dietary cellulose content in the adult. FEMS Microbiol Lett 1990; 69: 87-90.

40. Jensen BB. Methanogenesis in monogastric animals. Envir Monitoring Assess 1996; 42: 99-112.

41. Pace NR, Stahl DA, Lane DJ, Olsen GJ. The analysis of natural microbial populations by ribosomal RNA sequences. In: Marshall KC, ed. Advances in Microbial Ecology. New York: Plenum Press, 1986: 1-55.

42. Doré J, Stahl DA. Phylogeny of anaerobic rumen chytridiomycetes inferred from small subunit ribosomal RNA sequence comparisons. Can J Bot 1991; 69: 1964-71.

43. Doré J, Sghir A, Hannequart-Gramet G, Gorthier G, Pochart P. Design and evaluation of $16 \mathrm{~S}$ rRNA-targeted oligolucleotide probes for specific detection and quantitation of human fecal Bacteroides populations. Syst Appl Microbiol 1998; 21: $65-71$.

44. Montgomery L, Flesher B, Stahl D. Transfer of Bacteroides succinogenes (Hungate) to Fibrobacter gen. nov. as Fibrobacter succinogenes comb. and description of Fibrobacter intestinalis sp. nov. Int J Syst Bacteriol 1988; 38: 430-5.

45. Odenyo AA, Mackie RI, Stahl DA, White BA. The use of 16S ribosomal RNA targeted oligonucleotide probes to study competition between ruminal fibrolytic bacteria. Development of probes for Ruminococcus species and evidence of bacteriocin production. Appl Environ Microbiol 1994; 60: 3688-96. 